\title{
浴室環境を対象とした熱・水分・バイオエアロゾル輸送と 微生物増殖の数值解析 \\ COUPLED NUMERICAL ANALYSIS OF HEAT, MOISTURE AND MICROBE IN BATHROOM ENVIRONMENT
}

\author{
伊 藤一 秀*, 副 島勇 輝** \\ Kazuhide ITO and Yuki SOEJIMA
}

\begin{abstract}
Large numbers of studies have shown an association between living in homes with signs of 'dampness', and incidence and prevalence of airway diseases among children and adults. Damp house have possibility to encourage microbial growth which can increase the risk of adverse health effect and cause the deterioration of indoor air quality. In order to prevent health damage for residents in damp houses, the development of precise prediction method for indoor humidity and microbial condition in design stage is needed. This research focuses on the hygrothermal transport in residensial bathroom. Indoor environment in bathroom becomes high humidity during and after having a bath, and dew condensation on cold wall surfaces is one of the problems in view point of deterioration and disfigurement of building materials. We reports the procedure and the results of coupled numerical simlation incorporated with flow field analaysis and temerature/ humidity distribution in bathroom space and also reports the prediction mehod of microbial contamination in damp houses. Furthermore, microorganism growth on wall surfaces under high humidity environment is also confirmed to take countermeasures against contamination.
\end{abstract}

Keywords : Microbe, Heat, Moisture, Indoor Environment, CFD 微生物, 熱, 水分, 室内環境, 計算流体力学

1. 序

高湿度環境が出現する住宅内空間の代表として浴室が挙げられる. 我が国は世界的にみても入浴頻度が大変高く，その入浴頻度に応じ て浴室内に高温·高湿度環境が出現する．高湿度に伴う表面結露，建 材内での内部結露の発生は建材劣化の問題に加え，真菌に代表され る微生物増殖の問題を伴うことが多く, 健康影響や美観上の問題と して広く認知されている.

浴室内環境に関する研究事例は，例えば1980年代の田中らによる 浴室の必要換気量に関する検討結果 ${ }^{1)}$ に始まり, 湿度環境の調査, 評 価等に関する研究事例は既に多くの報告例がある。また高湿度環境 の数值予測に関しては, 結露時を含めた建材内の熱・水分同時移動解 析 ${ }^{2,3}$ や CFD(計算流体力学) との連成解析に関寸る報告例 ${ }^{4,5}$ が多くあ る。また住宅一般の湿度と微生物問題のキーワードであるダンプハ ウス(Damp House)問題に関しては，Wickmanらの報告")を始めとして 1990年代より欧米での報告事例が増加しており，近年では米国医学 研究所 $(\mathrm{IOM})$ 上り研究成果を取り纏めた良書 ${ }^{7}$ が出版されている. 室 内での高湿度問題は我が国での古くからの問題であるが，世界的に も重要な研究課題として注目を集めていると云えよう.

この分野は多くの研究蓄積があるものの，浴室等の高湿度環境を
対象として湿度予測から微生物増殖問題を一連の課題として扱う予 測シミュレーションに関する研究事例は少なく, 特にCFDを中心と した熱一水分の連成解析とバイオエアロゾルの輸送，更には壁面沈 着とその後の微生物増殖現象までを一連の解析として実施した事例 は皆無といえる．特に浴室内での真菌増殖現象に関して空間の不均 一性すなわち隅角部等での局所的な増殖が観察されることがあるが, これは真菌胞子の壁面沈着, 胞子沈着面の温湿度·養分等の条件の不 均一分布に起因寸ることが推察されるため, 予測精度の向上のため には浴室内の流れ場・温度場・湿度場予測から胞子輸送, 壁面沈着と 増殖現象を統合した枠組みで解析することが重要となる。浴室での 微生物増殖抑制を目指した室内環境設計を行う上での事前予測手法 が十分に整備されていないという点で, 湿度予測から微生物増殖を 一連の現象として予測可能なシミュレーション手法の開発は, 社会 的貢献度の高い研究課題と云えよう。

本研究では，一般的な住宅の浴室空間を対象として，浴室内に形 成される流れ場, 温度場, 湿度場の連成解析を行うと共に, 浴室開 口部より浴室内に移流される真菌胞子に代表されるバイオエアロゾ ルの移流・拡散現象, 浴室内壁面に対寸る不均一沈着量を定量的に予 測し, 沈着後の微生物増殖予測までを再現する一連の数值解析モデ

\footnotetext{
* 九州大学大学院総合理工学研究院 准教授. 工博

** 九州大学大学院総合理工学府 修士課程 
ルを提示し，一定の境界条件のもとで解析を実施した事例を報告す る. 本報では一連の数值解析モデルその解析事例の報告を目的とし ており, 胞子輸送と沈着から増殖に至る一連の微生物現象を対象と した実験的な検証は含んでいない。実験による精度検証に関しては 別報での報告を予定している.

\section{2. 解析対象空間}

本稿での解析対象として「建築学会標準問題モデル」の住戸モデ ルに対応する一般的な浴室を想定する ${ }^{8)}$. 浴室モデルの概略形状を図 1 に示寸. 浴室入りロドア下部に第3 種機械換気の流入開口を設置し,

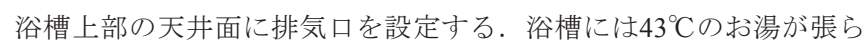
れている状態を仮定し，界面に一定温度を与えると共に水温に対応 した飽和水蒸気圧を与える。浴室壁面は $300 \mathrm{~mm} \times 300 \mathrm{~mm}$ サイズのタ イルと幅 $100 \mathrm{~mm} の$ 目地(モルタル)の2種類の建材より仕上げられてい ると想定する．浴槽側壁面の一部には密面に相当する壁面部分も設 定する.

\section{3. 計算手法の概要}

本報では浴室内の流れ場, 温度場, 湿度場をCFDを中心とした連 成解析にて算出し，その定常流れ場を用いてLagrange法により真菌 胞子をモデル化した粒子輸送と壁面沈着分布を解析する. その後, 浴室壁面に対する真菌胞子の不均一沈着量分布を初期条件として, 反応拡散系モデルを用いた真菌増殖解析を実施する. 壁体内の熱水 分移動と室内気流の時間スケールが大きく異なることを鑑み，壁体 内の熱水分同時移動解析をCFD解析とは独立して実施することで真 菌増殖モデルの入力条件とする簡便法を採用する.

\section{1 浴室空間での温度場, 湿度場と CFD 連成解析}

本研究ではCFD と温度場，湿度場を連成して解析する。流体の基 礎方程式であるNavier- Stokes式には, 温度差に起因寸る浮力生産項 と湿度差に起因する浮力生産項, 所謂含湿度浮力の両者を考慮する が，本研究では近藤ら ${ }^{4}$ による既往研究を基に定式化する．近藤らの 含湿度浮力モデルは単純化された線形モデルであり, そのモデル化 に対する実験的な精度検証は十分では無いとの指摘もあるが，一般 住宅内の浴室という限定された空間領域における湿度差に起因する 浮力効果の程度を確認する上では工学的有効性のあるモデルと考え られる。

本研究ではアンサンブル平均された方程式系を対象とし, 乱流モ デルとして低Re型k-ยモデル(Abe-Kondoh-Nagano model)を用いる．運 動方程式中の $S_{T}$ ならびに $S_{X}$ が各々温度差に起因する浮力生産項なら びに湿度差に起因する浮力生産項を示す. 支配方程式を表 1 に縓めて 示寸。本解析ではANSYS/FLUENT 12を用いて解析を実施した。

また一般的な浴室使用時間が壁体内での熱水分移動の時間スケー ルと比較して相対的に短いと仮定し，本解析では簡易的に浴室内で の流れ場，温湿度場の解析と壁体内部の熱水分同時移動解析は独立 して実施する。そのためCFD解析における壁面境界条件は，断熱， 断湿条件とし定常解析寸る.

\section{2 バイオエアロゾル輸送解析と壁面沈着量予測}

本研究では第三種換気される浴室内を対象として,ドア下部のガラ リ部分より室内に流入したバイオエアロゾルを Lagrange的に追跡し， 浴室内空気中での移流拡散の他, 最終的に壁面沈着量とその平面分布

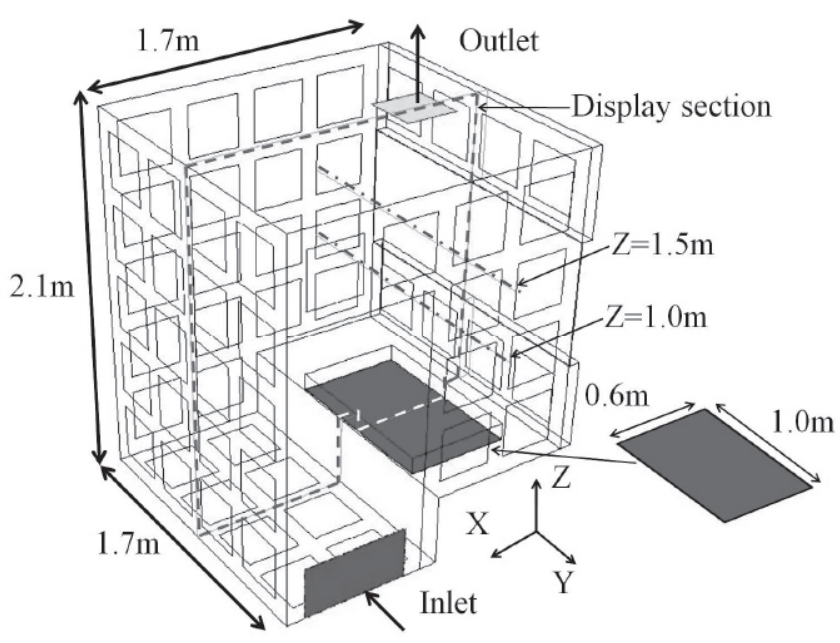

図 1 解析対象とする浴室空間モデル

表 1 流れ場・温度場・湿度場解析の支配方程式一覧

[1] 連続式

$$
\frac{\partial \bar{U}_{i}}{\partial x i}=0
$$

[2] 運動方程式

$$
\begin{aligned}
& \frac{\partial \bar{U}_{i}}{\partial t}+\frac{\partial \bar{U}_{i} \bar{U}_{j}}{\partial x_{j}}=-\frac{1}{\rho_{r}} \frac{\partial \bar{P}}{\partial x_{i}}+\frac{\partial}{\partial x_{j}}\left(v \frac{\partial \bar{U}_{i}}{\partial x_{j}}-\overline{u_{i} u_{j}}\right)+S_{T}+S_{X} \\
& S_{T}=-g_{i} \beta_{T}\left(\bar{T}-T_{r}\right) \\
& S_{X}=-g_{i} \beta_{X}\left(\bar{X}-X_{r}\right)
\end{aligned}
$$

[3] 熱輸送方程式

$$
\frac{\partial \bar{T}}{\partial t}+\frac{\partial \bar{U}_{i} \bar{T}}{\partial x_{i}}=\frac{\partial}{\partial x_{i}}\left(D_{T} \frac{\partial \bar{T}}{\partial x_{i}}-\overline{u_{i} t}\right)
$$

[4] 湿気輸送方程式

$$
\frac{\partial \bar{X}}{\partial t}+\frac{\partial \bar{U}_{i} \bar{X}}{\partial x_{i}}=\frac{\partial}{\partial x_{i}}\left(D_{X} \frac{\partial \bar{X}}{\partial x_{i}}-\overline{u_{i} x}\right)
$$

[5] 渦粘性係数, 相関項

$$
\begin{aligned}
& -\overline{u_{i} u_{j}}=v_{t}\left(\frac{\partial U_{i}}{\partial x_{j}}+\frac{\partial U_{j}}{\partial x_{i}}\right)-\frac{2}{3} k \delta_{i j} \quad \text { (7) } \quad v_{t}=C_{\mu} f_{\mu} \frac{k^{2}}{\varepsilon} \\
& -\overline{u_{i} t}=\frac{v_{t}}{\sigma_{T}} \frac{\partial \bar{T}}{\partial x_{i}} \quad \text { (9) } \quad-\overline{u_{i} x}=\frac{v_{t}}{\sigma_{X}} \frac{\partial \bar{X}}{\partial x_{i}}
\end{aligned}
$$

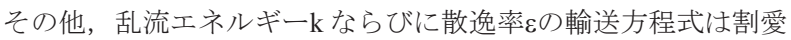

を解析する.本解析で使用した Lagrange モデルを表 2 に䋔めて示す. 粒子の輸送方程式を示す(11)式の右辺第一項は流体速度と粒子速度 に起因する抗力, 右辺第二項は重力沈降効果, 第三項は Saffman lift force(サフマン揚力)であり，Re $e_{p}$ は流体の粘性 $\mu$ を用いて定義される 粒子レイノルズ数, $C_{D}$ は抗力係数, $u$ は流体速度, $x_{p}$ は粒子位置, $u_{p}$ は粒子速度, $\rho_{p}$ は粒子密度, $g$ は重力加速度を示す。浴室内には不 均一温度分布が存在するため, 厳密には温度差に起因する熱泳動効果 を組み込む必要があるが, 既往研究報告よりその影響は無視可能な程 度小さいことを確認しており，本解析では考慮していない ${ }^{99}$ 。また低 Re 数領域では Saffman lift force の考慮が必要となるが，本解析では簡 易化のためにFs 項を無視している.

本解析では真菌胞子を単純球形にモデル化し，粒径 $D p=5 \mu \mathrm{m}$ ，粒 
子密度 $1.0 \mathrm{~g} / \mathrm{cm}^{3}$ を仮定して開口部位置より 10,000 個の粒子を瞬時に 発生させ, Lagrange 追跡を行う。また乱流変動を付加するため, (13) に示す DRW (discrete random walk)モデルを組み込むことで粒子輸送 に対する一定の確率変動を考慮している.

浴室壁面ならびに湯面に対する粒子の沈着現象は Wet deposition を 仮定し, 表面をP Perfect Sink と想定する. 即ち, 壁面に衝突した粒子 は完全にトラップされ, 跳ね返りや脱着現象は無いと仮定する.

\section{3 壁体内の熱水分同時移動解析}

本報で使用する建材内部の熱水分同時移動を示寸支配方程式を表 3 に示す. (14)式中の $T$ は温度 $\left[{ }^{\circ} \mathrm{C}\right], H$ はエンタルピー $\left[\mathrm{J} / \mathrm{m}^{3}\right]$ あ゙あり, 右辺第一項は伝導, 右辺第二項は水分流による熱流勾配を示す.また (15)式中の $\varphi$ は相対湿度[-], $w$ は含水率 $\left[\mathrm{kg} / \mathrm{m}^{3}\right]$ であり, 右辺は水蒸気 拡散ならびに水分拡散を示す.熱水分同時移動解析の基礎的な支配方 程式に関しては松本ら ${ }^{2,3)}$, 尾崎ら ${ }^{10)}$ が詳細な報告をしており, また 解析例も報告されているが, 特に両モデルでは解析を行う際に必要と なる物性値が異なる. 本解析では, IBP (Fraunhpfer Institute for Building Physics)より提供されている WUFI を用いて解析を行い, 計算に必要 となる物性值も IBP (Fraunhpfer Institute for Building Physics)のデータ ベースを利用する ${ }^{11}$.

本報では建材の厚さ方向のみを対象とする1次元解析を行う. 福岡 の外気条件すなわち時間変動する温湿度条件を与えた場合の室内側 の壁面表面温湿度解析を2週間(336h)実施する．浴室内の表面仕上げ の差異として, タイルと目地(モルタル)の 2 種類を解析対象とするが, 建築部材スケールでの面的な温湿度の不均一分布は無視可能である と仮定寸る。熱水分同時移動解析により建材表面温湿度を解析し, その結果を後述する真菌増殖モデルにフィードバックする.

\section{4 微生物増殖予測}

本解析では壁面に沈着した真菌胞子を污染源として壁面上で真菌 が増殖する様子を形態解析する

\section{4 .1 反応拡散系モデルによる真菌増殖解析}

筆者らは反応拡散系モデルによる真菌増殖モデルを提案し,その形 態予測精度を基礎実験と比較 ${ }^{12,13)}$ 寸ると共に, Abeによるカビ指数や WUFI-Bio といった他の増殖予測モデルと比較を行った結果 ${ }^{14)}$ を報告 している. 本解析に採用する反応拡散系モデルを基礎とする真菌増殖 モデルは, 活性度が高く増殖現象に寄与寸る真菌群密度 $u$ と活性度が 低くその場で蓄積する不活性真菌群 $v$ に大別して定式化すると共に, 建材表面での養分濃度 $n$ の輸送方程式の他，建材表面での温度·湿度 の影響を考慮したモデルである. 真菌増殖モデルの支配方程式群を表 4 に纏めて示寸.

活性真菌密度 $u$ の移動を表現する(16)式中の右辺第一項はランダム な真菌群移動を示寸拡散項を示し, 拡散係数は活性真菌密度 $u$ と養分 濃度の関数として(17)式で表現し, 乱数を用いた一定のノイズ $(-0.5<\delta<0.5)$ をえた解析を行う。(16)式中の右辺第二項は真菌 密度や養分, その他の環境因子による反応生成項を示し, 養分消費量 に対して一定の割合 $\theta$ にて真菌成長(増殖)に寄与すると仮定する。こ の $f(u, n)$ は，養分消費に伴うダンピングとして Michaelis- Menten 式を 適用し，(18)式で定式化する，本報では，真菌増殖の温度，湿度に対 する依存性は反応生成項に最も強く影響を与え, その結果として決定 される活性真菌密度 $u$ の濃度に依存寸る拡散係数((17)式)が間接的に 温湿度の影響を受ける, とのモデル化を採用する. (18)式中の $\zeta(T, \varphi)$
表 2 Particle Tracking (Lagrange)モデル

[6] 運動方程式

$$
\begin{aligned}
& \frac{d u_{p}}{d t}=\frac{18 \mu}{\rho_{p} d_{p}^{2}} \frac{C_{D} R e_{p}}{24}\left(u-u_{p}\right)+\frac{g\left(\rho_{p}-\rho\right)}{\rho_{p}}+F S \\
& \frac{d x_{p}}{d t}=u_{p} \quad \text { (12) } \quad u^{\prime}=\sigma \sqrt{2 k / 3}
\end{aligned}
$$

表 3 壁体内の熱水分同時移動解析の支配方程式

[7] 建材内熱水分同時移動方程式

$$
\begin{aligned}
& \frac{d H}{d T} \cdot \frac{\partial T}{\partial t}=\nabla \cdot(\lambda \nabla T)+h_{v} \nabla \cdot\left(\delta_{p} \nabla\left(\varphi p_{\text {sat }}\right)\right) \\
& \frac{d w}{d \varphi} \cdot \frac{\partial \varphi}{\partial t}=\nabla \cdot\left(D_{\varphi} \nabla \varphi+\delta_{p} \nabla\left(\varphi p_{\text {sat }}\right)\right)
\end{aligned}
$$

表 4 真菌密度の輸送方程式

[8] 活性真菌 $u$ の輸送方程式

$$
\begin{aligned}
& \frac{\partial u}{\partial t}=\nabla \cdot\left(D_{c} \nabla u\right)+\theta f(u, n)-a(u, n) u-\mu \\
& D_{c}=\sigma_{1}^{\prime} \cdot u \cdot n, \sigma_{1}^{\prime}=\sigma_{1}(1+\delta),-0.5<\delta<0.5 \\
& f(u, n)=\sigma_{2}\left(\frac{f_{1} n}{1+f_{2} n}\right) \cdot u \cdot \zeta(T, \varphi) \\
& \zeta(T, \varphi)=a_{1} \exp \left(a_{2} \varphi^{2}+a_{3} T^{2}+a_{4} \varphi^{*} T+a_{5} \varphi+a_{6} T+a_{7}\right) \\
& a(u, n)=\sigma_{3} \cdot \frac{1}{\left(1+\frac{u}{a_{1}}\right) \cdot\left(1+\frac{n}{a_{2}}\right)}
\end{aligned}
$$

\begin{tabular}{|c|c|c|c|c|}
\hline ケース & $T_{i n}, X_{i n}$ & $U_{i n}$ & 温度差浮力 & 含湿浮力 \\
\hline Case 1-1 & \multirow{4}{*}{$\begin{array}{l}25\left[{ }^{\circ} \mathrm{C}\right] \\
70[\%]\end{array}$} & \multirow{2}{*}{$\begin{array}{c}0.5 \mathrm{~m} / \mathrm{s} \\
\left(\mathrm{n}=59 \mathrm{~h}^{-1}\right)\end{array}$} & \multirow{4}{*}{$g \beta_{T}\left(\bar{T}-T_{r}\right)$} & - \\
\hline Case 2-1 & & & & $g \beta_{X}\left(\bar{X}-X_{r}\right)$ \\
\hline Case 3-1 & & \multirow{2}{*}{$\begin{array}{c}0.05 \mathrm{~m} / \mathrm{s} \\
\left(\mathrm{n}=5.9 \mathrm{~h}^{-1}\right)\end{array}$} & & - \\
\hline Case 4-1 & & & & $g \beta_{X}\left(\bar{X}-X_{r}\right)$ \\
\hline ケース & $T_{i n}, X_{i n}$ & $U_{\text {in }}$ & 温度差浮力 & 含湿浮力 \\
\hline Case 1-2 & \multirow{4}{*}{$\begin{array}{l}15\left[{ }^{\circ} \mathrm{C}\right] \\
70[\%]\end{array}$} & \multirow{2}{*}{$\begin{array}{c}0.5 \mathrm{~m} / \mathrm{s} \\
\left(\mathrm{n}=59 \mathrm{~h}^{-1}\right)\end{array}$} & \multirow{4}{*}{$g \beta_{T}\left(\bar{T}-T_{r}\right)$} & - \\
\hline Case 2-2 & & & & $g \beta_{X}\left(\bar{X}-X_{r}\right)$ \\
\hline Case 3-2 & & \multirow{2}{*}{$\begin{array}{c}0.05 \mathrm{~m} / \mathrm{s} \\
\left(\mathrm{n}=5.9 \mathrm{~h}^{-1}\right)\end{array}$} & & - \\
\hline Case 4-2 & & & & $g \beta_{X}\left(\bar{X}-X_{r}\right)$ \\
\hline
\end{tabular}

[9] 不活性真菌 $v$ の輸送方程式

$$
\frac{\partial v}{\partial t}=a(u, n) u
$$

[10] 養分 $n$ の輸送方程式

$$
\frac{\partial n}{\partial t}=D_{n} \nabla^{2} n-f(u, n)
$$

表 5 流れ場解析ケース一覧

は真菌増殖に対する温湿度依存性を示し, 本報では(19)式にて表現す る(温湿度依存性の定式化，モデル定数の同定に関する詳細は既報 ${ }^{14)}$ 参照). (16)式右辺第三項は真菌密度 $u$ に依存寸る不活性真菌群 $v$ 一の 変換項, (21)式は不活性真菌 $v$ の輸送方程式を示し, 活性真菌が一定 割合で変換され，その場で蓄積して移動しないとのモデル化である. 
また, (22)式は養分量 $n$ の輸送方程式を示し, 真菌の個体群密度に応 じた養分消費に加え, 濃度勾配に応じて 2 次元平面上で拡散を仮定し た定式化である。

本報で採用する真菌増殖モデルは建材表面の 2 次元平面を対象と し, タイル 4 枚分を含む $800 \mathrm{~mm} \times 800 \mathrm{~mm}$ 領域を解析対象とし，建材 内部一の菌系増殖は無視している(解析領域の詳細は後述).

\section{4 .2 真菌胞子の発芽条件モデル}

3.2 節で示した真菌胞子の壁面沈着量分布予測では, 真菌胞子を仮 定した粒子を個別に Lagrange 追跡することで, 壁面上での不均一沈 着量分布の解析を行う. その結果として, 定常流れ場を対象として瞬 時に発生した 10,000 個の粒子追跡による壁面での不均一沈着量分布 が示されることになる.一般に壁面に付着した真菌胞子全てが発芽し 菌系成長する訳ではなく, また発芽・増殖には真菌密度に対する一定 の依存性も指摘されている. 即ち, 真菌胞子の壁面付着量と発芽, そ の後の反応拡散系モデルによる増殖予測に関しては, 何らかのモデル 化によるシームレスな結合が必要となる。この点に関しては理論的・ 実験的見解が十分に整理されているとは言い難いため, 本研究では壁 面に付着した粒子は必ず発芽・増殖すると仮定し，その粒子 1 個は活 性真菌 $u$ の密度 $1 / \mathrm{mm}^{2}$ に相当するとして解析を実施する。

\section{4. 数值解析条件と解析ヶース}

本報では, 図 1 に示寸浴室モデルに対し, 流入風速レベルを 2 段階 $\left(U_{\text {in }}=0.5 \mathrm{~m} / \mathrm{s}, 0.05 \mathrm{~m} / \mathrm{s}\right)$, 温度差ならびに湿度差に起因する浮力生産項 の有無により, 表 5 に示すとおり 8 ケースの流れ場解析ケースを設定 する. 流れ場, 温度場ならびに湿度場解析の数值解析条件を纏めて表 6 に示寸. 中間期の温湿度を想定したケースでは, 流入温度 $T_{\text {in }}$ を 15 $\left[{ }^{\circ} \mathrm{C}\right]$, 絶対湿度 $X_{\text {in }}$ を $7.42 \times 10^{-3}\left[\mathrm{~kg} / \mathrm{kg}{ }^{\prime}\right]\left(=70 \% \mathrm{RH}\right.$ at $\left.15^{\circ} \mathrm{C}\right)$ に設定した。

その後, 含湿浮力を考慮した相対的に高換気量の Case 2-2 ならびに 低換気量の Case 4-2 の定常流れ場を元に, 流入開口部より瞬時に 10,000 個の粒子を発生させた場合の Lagrange 追跡を行い, Perfect Sink を仮定した壁面に対する沈着量分布を解析する.

更に, この不均一沈着量分布を元に, 図 2 ならびに図 8 , 9 に示寸 $800 \mathrm{~mm} \times 800 \mathrm{~mm}$ の 2 次元壁面を対象として反応拡散系モデルによる 真菌増殖予測を行う。この解析では相対的に換気量の多い Case 2 の 流れ場を元に解析した真菌胞子沈着量分布と, 相対的に換気量の少な いCase 4 の流れ場を元に解析した真菌胞子沈着量分布の 2 条件を解 析の初期条件として用いる. 反応拡散系モデルによる真菌増殖の形態 解析では, 既往研究 ${ }^{14)}$ で用いたモデルパラメータを適用して解析を 行う。この值はPDA 培地上での菌系増殖に関する基礎実験結果 ${ }^{12,13)}$ との整合を考慮した上で, 1 週間程度の時間スケールを対象とした場 合に WUFI-Bio による建材上での菌系長予測結果とほぼ整合するよ うにチューニングしたものである ${ }^{14)}$.

また反応拡散系モデルによる真菌増殖モデルの温湿度依存性を (19)式で組み込むため, コンクリート十断熱材十石膏ボード+タイル (もしくはモルタル)より構成される壁体を想定し, 室内側建材表面の 温度ならびに湿度変動を解析する. 壁体モデルを図 2 に示す. 想定し た壁体の条件, 物性值を表 8 に示寸. また壁体内熱水分同時移動解析 の境界条件を表 9 に示寸. 福岡の中間期(6/13 から 6/27)の標準気象デ
表 6 流れ場等の計算・境界条件

\begin{tabular}{l|l}
\hline Turbulence model & Low Re Type k- $\varepsilon$ model \\
\hline Total mesh & 800,000 unstructured mesh \\
\hline \multirow{2}{*}{ Scheme } & $\begin{array}{l}\text { Convection term: QUICK, } \\
\text { Diffusion term: second order center difference }\end{array}$ \\
\hline \multirow{3}{*}{ Inflow boundary } & $\begin{array}{l}\text { Size of opening }: 300 \times 600[\mathrm{~mm}], \mathrm{U}_{\text {in }}=0.5 \text { and } 0.05 \\
{[\mathrm{~m} / \mathrm{s}], \mathrm{k}_{\text {in }}=3 / 2\left(\mathrm{U}_{\text {in }} \times 0.1\right), \varepsilon_{\text {in }}=\mathrm{C}_{\mu}{ }^{3 / 4} \times \mathrm{k}_{\text {in }}{ }^{3 / 2} / 0.03, \mathrm{~T}_{\text {in }}=15} \\
{\left[{ }^{\circ} \mathrm{C}\right], \mathrm{X}_{\text {in }}=7.42 \times 10^{-3}\left[\mathrm{~kg} / \mathrm{kg}{ }^{\prime}\right]\left(=70 \% \mathrm{RH} \text { at } 15^{\circ} \mathrm{C}\right)}\end{array}$ \\
\hline \multirow{2}{*}{ Outflow boundary } & $\begin{array}{l}\text { Size of opening }: 300 \times 300(\mathrm{~mm}), \\
\mathrm{U}_{\text {out }}, \mathrm{k}_{\text {out }}, \varepsilon_{\text {out }}=\text { Free slip }\end{array}$ \\
\hline \multirow{2}{*}{ Wall treatment } & $\begin{array}{l}\left.\text { Surface of hot water in bathtub : T=43 [ }{ }^{\circ} \mathrm{C}\right], \\
\mathrm{X}=0.0593[\mathrm{Kg} / \mathrm{Kg}], \text { Other wall surfaces : Adiabatic }\end{array}$ \\
\hline
\end{tabular}

表 7 反応拡散系モデルの計算・境界条件

\begin{tabular}{|c|c|}
\hline Cal. period & Total 336h, \\
\hline $\begin{array}{l}\text { Temp. and RH } \\
\text { condition on wall } \\
\text { surface }\end{array}$ & $\begin{array}{l}\text { Results of hygrothermal analysis (in Fig. } 7 \text { ), or } \\
\text { Temp : } 25^{\circ} \mathrm{C} \text { constant and } \mathrm{RH}: 0.95 \text { constant }\end{array}$ \\
\hline $\begin{array}{l}\text { Model parameter of } \\
\text { Reaction diffusion } \\
\text { model }\end{array}$ & $\begin{array}{l}\sigma_{l}=5.0 \times 10^{-5}, \quad \sigma_{2}=3.0, \quad f_{l}=1.0, \quad f_{2}=1.0, \theta=5.0 \times 10^{2}, \\
\sigma_{3}=5.0, \quad a_{1}=1 / 2400, a_{2}=1 / 120, n_{0}=1.0 \text { for PDA, } \\
D_{n}=1.0 \times 10^{-8}, u_{0} \text { (center) }=1.0, v_{0}=0.0\end{array}$ \\
\hline $\begin{array}{l}\text { Model parameter of } \\
\zeta(T, \varphi)\end{array}$ & $\begin{array}{l}a_{1}=0.840, \quad a_{2}=-132.403, \quad a_{3}=-0.009, \quad a_{4}=-0.943 \\
a_{5}=269.292, \quad a_{6}=1.350, \quad a_{7}=-141.976\end{array}$ \\
\hline
\end{tabular}

表 8 壁体モデルの構成

\begin{tabular}{l|l|l}
\hline Analytical model & Case_Tile & Case_Joint \\
\hline \multirow{3}{*}{ Wall composition } & Concrete (150mm) & Concrete (150) \\
(thickness) & Insulation Board (25) & Insulation Board (25) \\
& Air layer (25) & Air layer (25) \\
& Gypsum Plaster (10) & Gypsum Plaster (10) \\
& Tile (5) & Mortar (5) \\
\hline
\end{tabular}

表 9 壁体内熱水分同時移動解析の境界条件

\begin{tabular}{|c|c|}
\hline Calculation period & Total 336h, Time Steps:1[h], Start:06/13, End:06/27 \\
\hline $\begin{array}{l}\text { Initial Condition } \\
\text { (wall inside) }\end{array}$ & $\begin{array}{l}\text { Initial Temperature }\left[{ }^{\circ} \mathrm{C}\right]: 15^{\circ} \mathrm{C} \text {, } \\
\text { Initial Relative Humidity[-] }: 0.7 \\
\text { Initial Water Content }\left[\mathrm{kg} / \mathrm{m}^{3}\right] \text { of Concrete: } 41.3 \text {, } \\
\text { Insulation Board : } 0.16, \text { Gypsum Plaster }: 1.13\end{array}$ \\
\hline Indoor Climate & $\begin{array}{l}\text { Temperature }\left[{ }^{\circ} \mathrm{C}\right]: 15^{\circ} \mathrm{C} \text { constant, } \\
\text { Relative Humidity }[-]: 0.7 \text { constant } \\
\text { CHTC }: 8\left[\mathrm{~W} / \mathrm{m}^{2} / \mathrm{K}\right]\end{array}$ \\
\hline Outdoor Climate & $\begin{array}{l}\text { Fukuoka; AMeDAS standard year }(06 / 13 \text { to } 06 / 27) \\
\text { CHTC : } 17\left[\mathrm{~W} / \mathrm{m}^{2} / \mathrm{K}\right]\end{array}$ \\
\hline
\end{tabular}

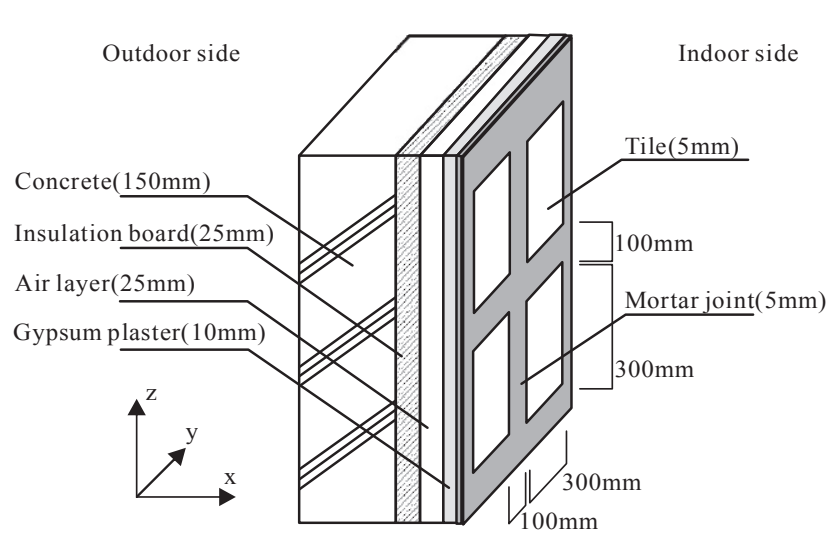

図 2 壁体モデル

ータを外気条件として 2 週間の解析を行う。 


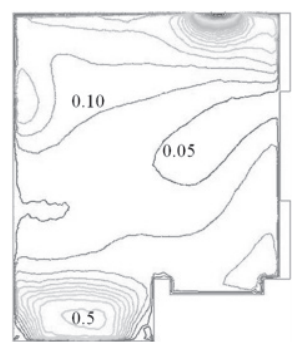

(1) Case 1-1 [m/s]

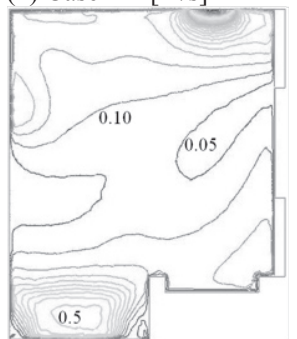

(4) Case 2-1 [m/s]

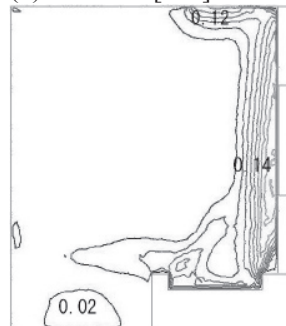

(7) Case $3-1[\mathrm{~m} / \mathrm{s}]$

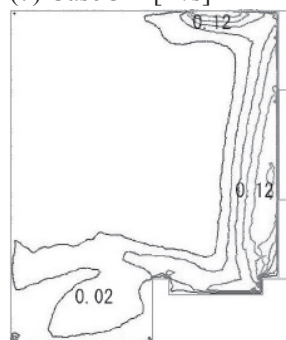

(10) Case 4-1 [m/s]

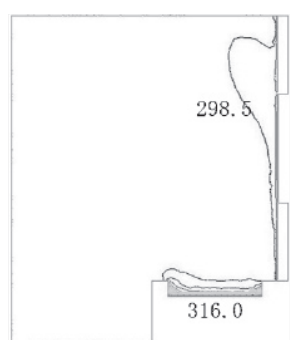

(2) Case 1-1 [K]

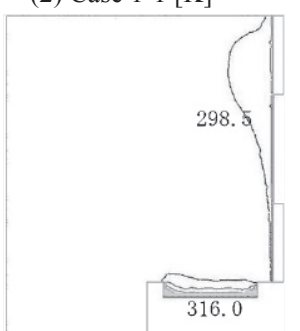

(5) Case 2-1 [K]

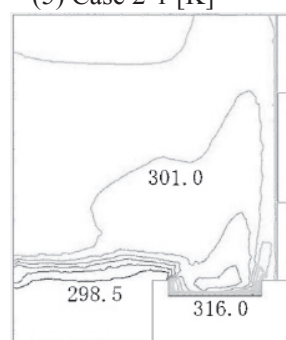

(8) Case 3-1 [K]

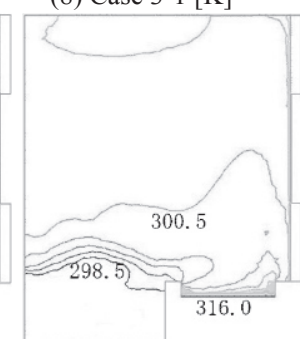

(11) Case 4-1 [K]

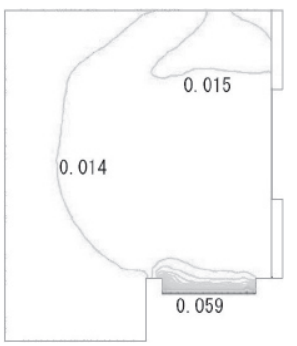

(3) Case 1-1 [kg/kg']

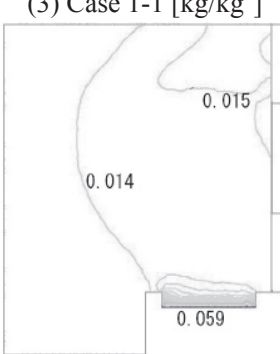

(6) Case 2-1 [kg/kg']

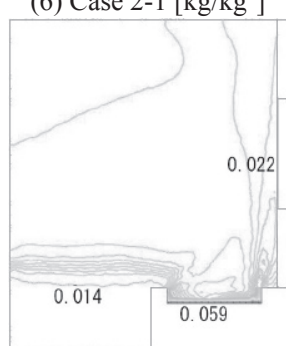

(9) Case 3-1 [kg/kg']

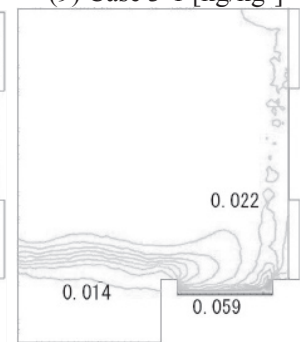

(12) Case 4-1 [kg/kg']

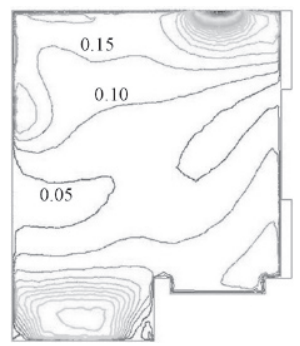

(13) Case 1-2[m/s]

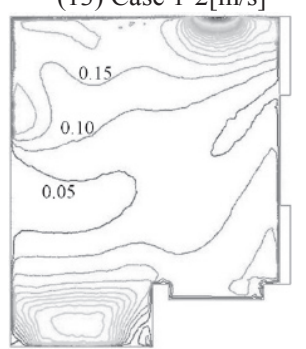

(16) Case 2-2[m/s]
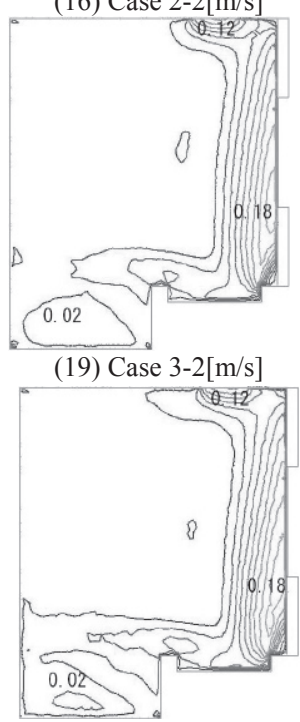

(22) Case 4-2[m/s]

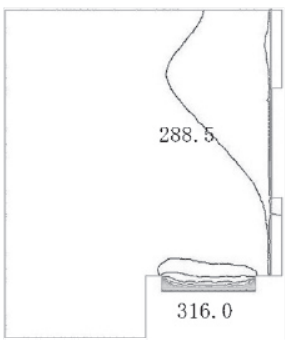

(14) Case 1-2 [K]

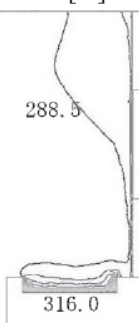

(17) Case 2-2 [K]

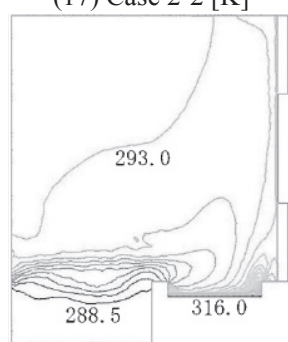

(20) Case 3-2 [K]

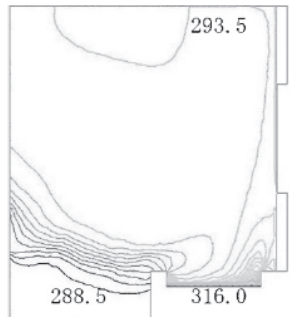

(23) Case 4-2 [K]

図 3 スカラ風速分布 $[\mathrm{m} / \mathrm{s}]$, 温度分布 $[\mathrm{K}]$, 絶対湿度分布解析結果 $[\mathrm{kg} / \mathrm{kg}$ ']

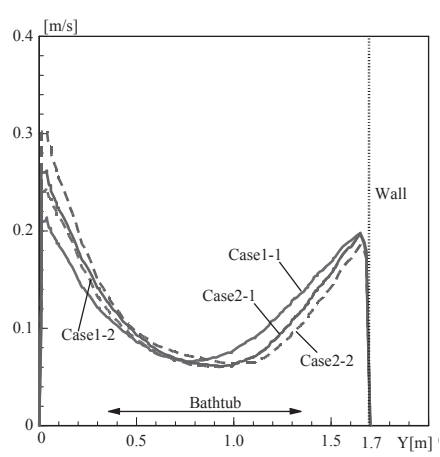

(1) $U_{i n}=0.5 \mathrm{~m} / \mathrm{s}, Z=1.0[\mathrm{~m}]$ 位置

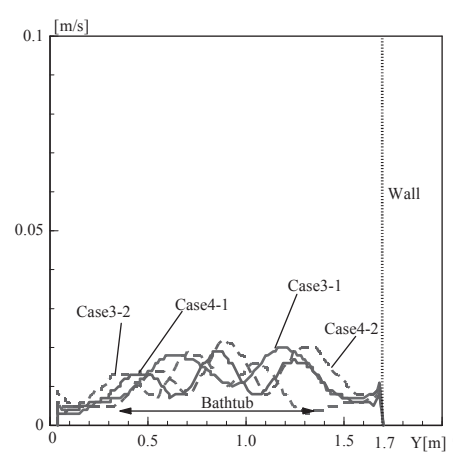

(2) $U_{i n}=0.05 \mathrm{~m} / \mathrm{s}, Z=1.0[\mathrm{~m}]$ 位置

図 4 浴場上部でのスカラ風速分布比較

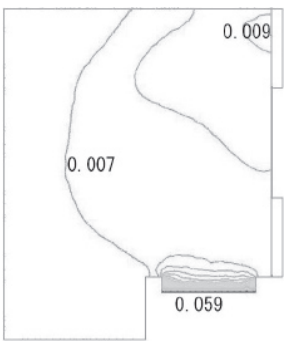

(15) Case $1-3[\mathrm{~kg} / \mathrm{kg}$ ']

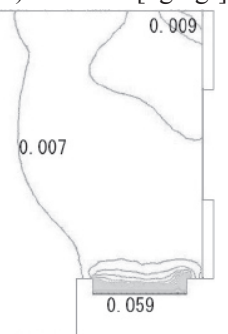

(18) Case 2-3 [kg/kg']

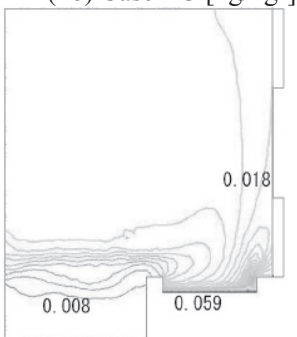

(21) Case $3-3[\mathrm{~kg} / \mathrm{kg}$ ']

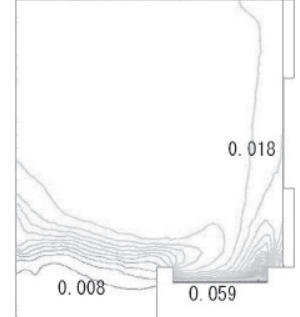

(24) Case 4-3 [kg/kg']

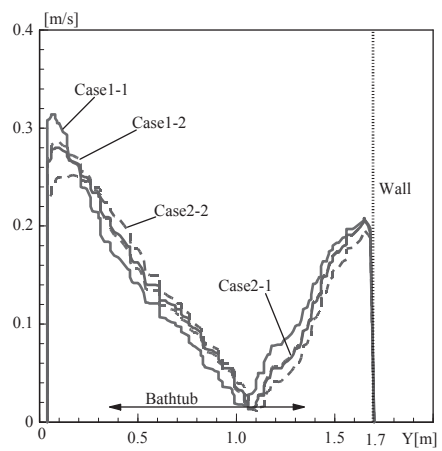

(3) $U_{\text {in }}=0.5 \mathrm{~m} / \mathrm{s}, Z=1.5[\mathrm{~m}]$ 位置

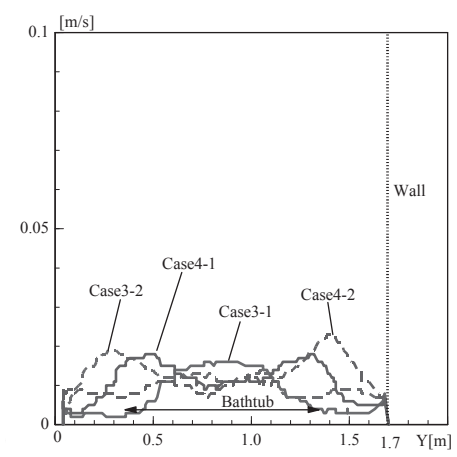

(4) $U_{\text {in }}=0.05 \mathrm{~m} / \mathrm{s}, Z=1.5[\mathrm{~m}]$ 位置

\section{5. 数値解析結果}

\section{1 浴室内流れ場解析結果}

図 1 中の赤色点線部分で示した断面のスカラ風速分布解析結果を 困 3 に示す. また浴槽上部の $\mathrm{z}=1.0 \mathrm{~m}$ ラインならびに $\mathrm{z}=1.5 \mathrm{~m}$ ライン(図 1 参照)にて各解析ケースの風速分布を比較した結果を図 4 に示す. 温度差のみによる浮力項を組み込んだ 4 ケースと温度差に加え湿度 差による浮力項を組み込んだ 4 ケースを比較すると, 壁面近傍の風速
分布に若干の差異が見られるものの, 浴室全体では差異はなく, 解析 対象とした浴室においては湿度差による浮力は無視可能なオーダで あると云える.本解析条件では温度差の浮力に対して湿度差による浮 力は $1 / 6$ 程度以下であり，このオーダは既往研究での報告例とほぼ整 合する結果であった ${ }^{4}$

\section{2 浴室内温度場ならびに湿度場解析結果}

図 1 中の赤色点線部分で示した断面の温度分布ならびに湿度分布 

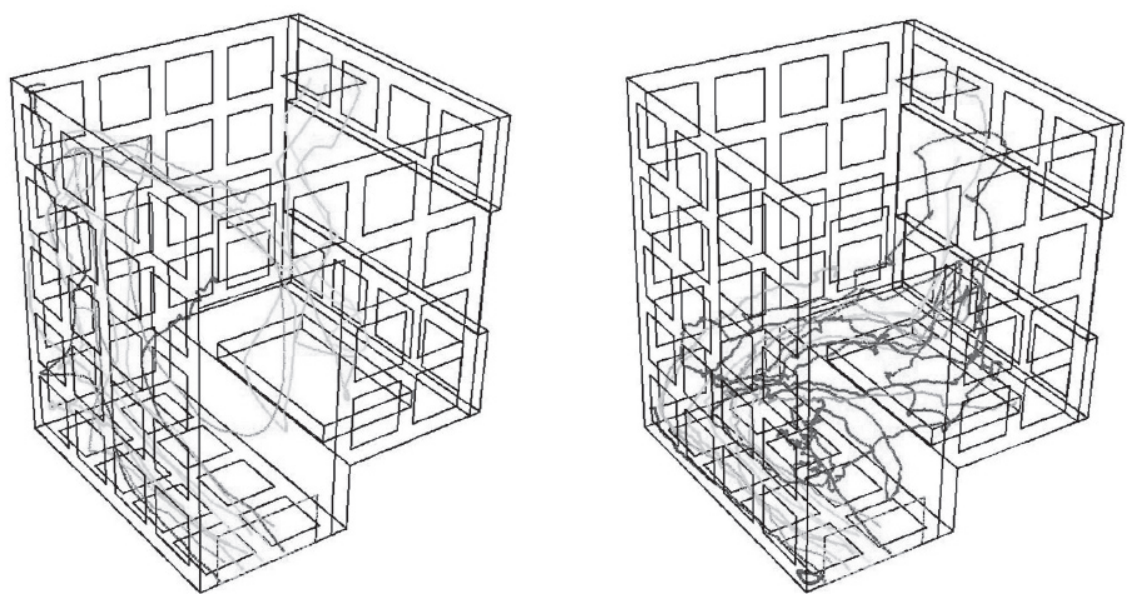

(1) High ventilation case ( $U_{i n}=0.5 \mathrm{~m} / \mathrm{s}$, Case 2-2 流孔場を対象 $) \quad$ (2) Low ventilation case ( $U_{i n}=0.05 \mathrm{~m} / \mathrm{s}$, Case $4-2$ 流れ場を対象) 図 5 真菌胞子を仮定した粒子の流跡線
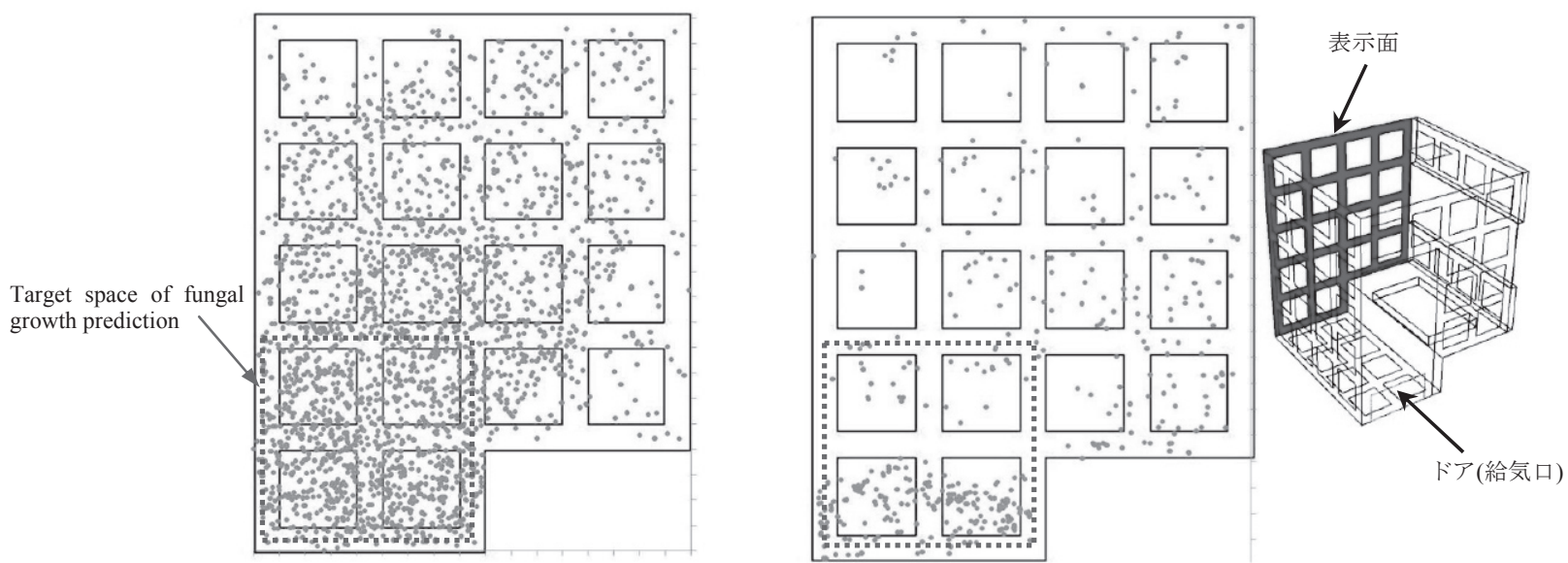

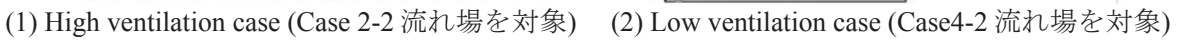
図 6 真菌胞子の沈着量分布 (吹出口から見た対向壁面)

解析結果を図 3 に併せて示寸，相対的に高風速に設定した Case 1 な らびに Case 2 では浴室内が攪拌されるため温度分布ならびに湿度分 布ともにほぼ均一となる。低風速のケース(Case 3，4)では発熱·放湿 源である浴槽上部にて温度成層が確認できる。

\section{3 真菌胞子の Lagrange 解析結果}

Lagrange 追跡を実施した 10,000 個の粒子の中で代表的な粒子 10 個の流跡線を図 5 に示寸. 本解析では粒径 $D p=5 \mu \mathrm{m}$ を仮定している ため, 重力沈降は支配的とならず,ほぼ流れ場に沿って輸送される. 吹出風速 $U_{i n}=0.5 \mathrm{~m} / \mathrm{s}$ に設定した Case 2-2 の流れ場を対象とした解析 では，吹出気流が対向壁に衝突し，その後に上昇する流れ場に従っ て粒子輸送される様子が確認できる。相対的に低風速である $U_{i n}=0.05 \mathrm{~m} / \mathrm{s}$ に設定した Case 4-2 の流れ場を対象とした解析では, 吹 出気流と比較して浴槽面上部での浮力効果が大きいため，浴室内に 流入した粒子は浴槽上部に輸送され，浴室内を浮遊する様子が確認 できる.

また，入口ドア下部の流入口からみた対向壁の粒子沈着分布を図 7 に示寸. Case 2-2 の流れ場を対象とした場合に吹出口対向壁下部に 多くの粒子が沈着する結果となっている. 表 10 に各壁面での粒子沈 着量の割合を示す，換気量を多く設定することで浴室内から排出さ れる粒子数は多くなるものの, 吹出噴流が衝突する領域では粒子沈 着量が多くなるため，壁面に対する粒子沈着分布は流れ場性状に強
表 10 粒子沈着量分布

\begin{tabular}{l|c|c}
\multicolumn{1}{c|}{ 沈着面 } & $\begin{array}{c}\text { Case 2-2 } \\
\left(U_{\text {in }}=0.5 \mathrm{~m} / \mathrm{s}\right)\end{array}$ & $\begin{array}{c}\text { Case 4-2 } \\
\left(U_{i n}=0.05 \mathrm{~m} / \mathrm{s}\right)\end{array}$ \\
\hline 給気口から見た対向壁面 & $21.9[\%]$ & $4.9[\%]$ \\
\hline 給気口から見た左側壁面 & $9.0[\%]$ & $9.4[\%]$ \\
\hline 給気口から見た右側壁面(空) & $4.7[\%]$ & $17.6[\%]$ \\
\hline 給気口を含む壁面(ドア) & $13.6[\%]$ & $4.3[\%]$ \\
\hline 天井面 & $8.6[\%]$ & $3.1[\%]$ \\
\hline 床面(浴槽含まず) & $6.5[\%]$ & $16.7[\%]$ \\
\hline 浴槽面 & $7.7[\%]$ & $30.7[\%]$ \\
\hline 換気(排気口) & $28.0[\%]$ & $13.3[\%]$ \\
\hline
\end{tabular}

35 Temp [deg.C]

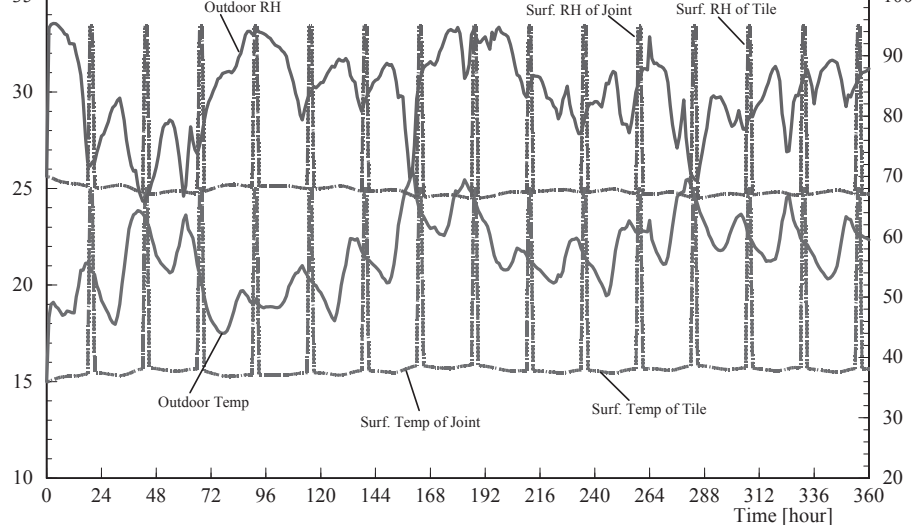

図 7 建材表面での温度·湿度履歴解析結果 

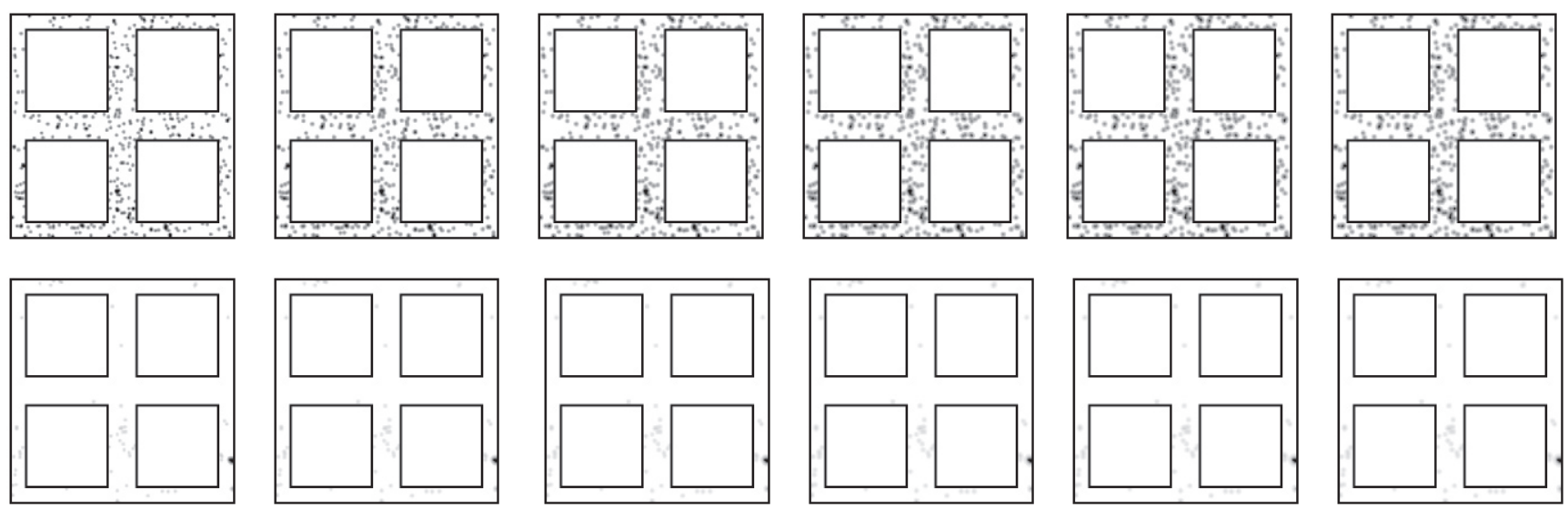

(1) $t=24 h$

(2) $\mathrm{t}=48 \mathrm{~h}$

(3) $\mathrm{t}=72 \mathrm{~h}$

(4) $\mathrm{t}=144 \mathrm{~h}$

(5) $\mathrm{t}=216 \mathrm{~h}$

(6) $\mathrm{t}=336 \mathrm{~h}$

図 8 反応拡散モデルによる真菌増殖 $(u+v)$ 予測結果 (図 7 の建材表面温湿度データを入力条件 $\left(15^{\circ} \mathrm{C}, 70 \% \mathrm{RH}\right.$ 条件)) (上図：Case 2-2 の高風速条件/下図：Case 4-2 の低風速条件)
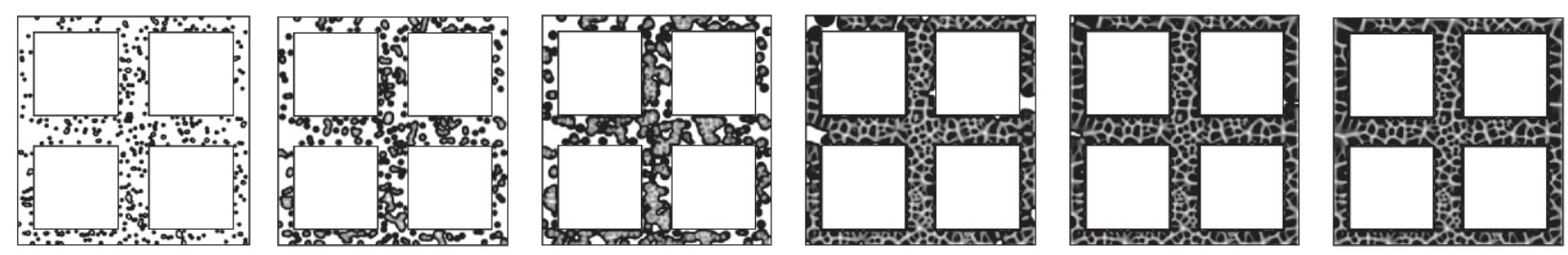

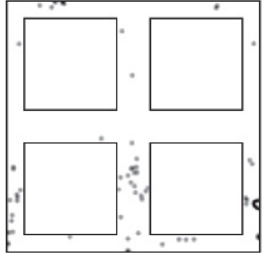

(1) $\mathrm{t}=24 \mathrm{~h}$

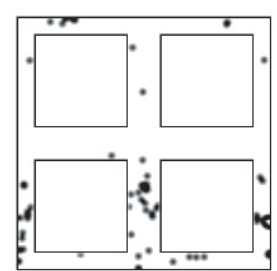

(2) $\mathrm{t}=48 \mathrm{~h}$

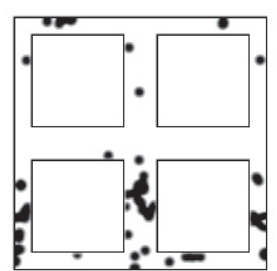

(3) $\mathrm{t}=72 \mathrm{~h}$

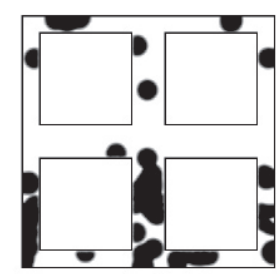

(4) $\mathrm{t}=144 \mathrm{~h}$

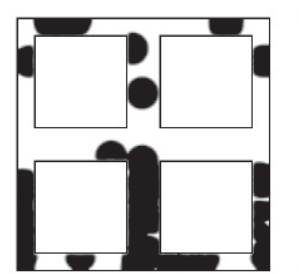

(5) $t=216 h$

図 9 反応拡散モデルによる真菌増殖 $(u+v)$ 予測結果 $\left(25^{\circ} \mathrm{C}, 95 \% \mathrm{RH}\right.$ 一定条件 $)$ (上図 : Case 2-2 の高風速条件/下図 : Case 4-2 の低風速条件)

く依存することが確認できる.

\section{4 壁体内の熱水分同時移動解析結果}

図 7 に図 2 に示寸壁体モデルを対象として福岡中間期の外気条件に て室内側建材表面の温湿度履歴を解析した結果を示す。本解析では, 室内側空気の温湿度が $15^{\circ} \mathrm{C}, 70 \% \mathrm{RH}$ 一定に制御されており, 入浴時 間を想定した午後 7 時から 9 時までの 2 時間のみ室内側空気条件が $25^{\circ} \mathrm{C}, 95 \% \mathrm{RH}$ になるとの境界条件にて解析した結果である. 本解析 では, 入浴に伴う液相水分の飛散と壁面付着, 結露等は考慮していな い注 ${ }^{1)}$ 。浴室側の設定スケジュールに応じて入浴想定時間に浴室内の 温湿度が上昇し, それに伴い室内側壁面表面温度も上昇するが, 室内 側空気の温湿度設定が $15^{\circ} \mathrm{C}, 70 \% \mathrm{RH}$ に戻ると速やかに室内側壁面表 面温度も変化する結果となっている. 即ち, 表 8 ならびに表 9 に示し た本報での解析条件では, 使用した建材の水分拡散係数の才ーダと比 較して解析時間が非常に短時間(336h)での解析であるため, 壁体内で の初期含水率分布や外気湿度変動の影響が小さく, 浴室側の建材表面 湿度は浴室側建材表面の物質伝達抵抗にてほぼ決定されてしまう条 件となっている.

真菌胞子の沈着から増殖までを解析対象とする場合には本報での 解析時間スケールで十分と云えるが, 真菌増殖リスクの評価には年才 ーダの長期的な解析が必要となる.

5.5 壁面上での真菌増殖予測結果
反応拡散モデルによる建材表面での真菌増殖予測結果を図 8 なら びに図 9 に示寸. 本解析では, 真菌増殖に直接寄与寸る有効養分 $n$ にて真菌増殖の建材種依存性を表現するため, タイル部分の初期有効 養分 $n$ はゼロ, 目地部分の初期有効養分 $n$ を 1 として解析を実施した. 図 8 は図 7 に示した壁体内の熱水分同時移動解析による室内側建材表 面の温度ならびに湿度を表 4 中の(19)式にて考慮することで温湿度ダ ンピングを考慮した結果を示しており, また図 9 は建材表面の温湿度 が入浴時を想定した $25^{\circ} \mathrm{C}, 95 \% \mathrm{RH}$ 一定条件に調整された場合の結果 を示す.

福岡中間期の外気条件を考慮して室内側の温湿度変動を考慮した 図 8 の結果より,この解析条件では, 壁面に付着した真菌は増殖を開 始寸るものの解析開始より $72 \mathrm{~h}$ 程度で成長速度が低下し, 真菌増殖分 布も $72 \mathrm{~h}$ 以降は一定となった. また, 入浴時の条件が定常的に継続さ れると想定した条件(図 9)では, 沈着量の多い, 即ち真菌増殖モデル の初期入力值の多い高風速ケース(Case 2-2)にて活性真菌 $u$ ならびに 不活性真菌 $v$ の生成速度が大きくなり, 解析開始後 $144 \mathrm{~h}$ で対象壁面 の目地部分を覆い尽くすほど増殖する結果となった。

\section{6. 考察}

本報では高湿度となりうる浴室空間を対象として流れ場, 温度場な らびに湿度場の連成解析を行うと共に, 浮遊真菌胞子をモデル化した 
球形粒子の Lagrange 追跡を行うことで，壁面沈着量分布の予測結果 を示した.さらに粒子沈着位置を真菌増殖発生源とした真菌増殖の形 態解析を実施した結果を示した. 本報での解析を一連の解析プロセス として実施することで, 浴室内での高湿度問題と微生物污染問題を纏 めて予測することが可能となる.

しかしながら, 本解析では, (i) 壁体内の熱水分同時移動と CFD 解 析を同時に連成して実施しておらず,この点で微生物増殖に支配的な 影響を与える建材表面温度・湿度ならびに自由水量等の予測精度に問 題がある. 更に, (ii)真菌胞子の沈着量と発芽・増殖に実現象を再現可 能な予測モデルが導入されていない, (iii)反応拡散系の増殖モデルを 採用したが，複数のモデルパラメータが物理化学的・生物学的な合理 性より同定されておらず, 試行錯誤的にフィッティングされているこ と, 等に汎用化に向けた課題があり, 実験実測結果を用いた検証が必 要であると考えている.

繰り返しになるが, 本報では室内の流れ場, 温度場ならびに湿度場 と壁体内の水分移動, 更には真菌胞子輸送を解析し, 反応拡散モデル にて真菌増殖までを予測する一連の解析手順を提示し, 一定の境界条 件の基での解析を実施した事例を報告するとの段階に留まっている. 前述した(i)から(iii)の個別課題に関しては今後更に研究を進展させ, 汎用的な予測手法としての精度向上を目指した改善が必要である.

\section{7. 結論}

本報で得られた知見を纒めると以下の通りである.

(1)浴室空間を対象として温度差による浮力モデル, 湿度差による浮 力モデルを組み込んだ流れ場解析を実施した結果, 空間体積が限 定されている一般住宅の浴室では, 既往研究での指摘のとおり, 含湿浮力モデルが流れ場予測精度に与える影響は小さく無視可能 であることが確認された。

(2)定常流れ場解析結果を基に浮遊真菌胞子をモデル化した球形粒子 の Lagrange 解析を行った結果, 相対的に換気回数の大きい( $\mathrm{n}=59$ $\left.\mathrm{h}^{-1}\right)$ 解析ケースにおいて, 吹出気流が衝突する吹出口の対向壁下部 一の胞子沈着量が大きく, 換気回数の小さい $\left(\mathrm{n}=5.9 \mathrm{~h}^{-1}\right)$ 解析ケース では, 流入した粒子は浴槽上部の熱上昇流に誘引され室上部に輸 送されるため, 床面や吹出口の対向壁下部への沈着量は小さくな る. 真菌胞子の壁面沈着量は換気量が大きくなれば単純に減少す る訳ではく, 流れ場の性状に強く依存する事が確認された。

(3) 反応拡散系モデルによる真菌増殖モデルをタイルと目地より構成 された浴室壁面に適用し, 実時間で 2 週間の解析を実施した。建 材表面に有効養分 $n$ を設定することで, 建材種が異なる場合の真 菌増殖速度の相違を表現する簡易モデルを示した。

（4）本報では流れ場予測から真菌増殖に関する形態予測までを一連の プロセスとして解析する手順を示した. 真菌胞子輸送から壁面沈 着, 真菌増殖までを含めた一連の解析に対する予測精度の検証は 今後の課題である.

\section{謝辞}

本研究の一部は科学研究費補助金 (課題番号 21676005)の助成を受 けたものである. 記して深甚なる謝意を示す.
注 1) 建材表面での真菌増殖には雾囲気の温湿度の他, 建材中の自由水量や $\mathrm{pH}$ も大きな影響を与えることが知られている.この点で結露を含んだ 液相での水分移動を高精度に予測することは, 真菌增殖現象の予測モデ ル構築の上では重要な課題である. 現時点では反応拡散系モデルをべー スとする真菌増殖モデル中に液相の水分量の効果を陽に示す反応項を 考慮していないため, 壁体中の熱水分移動に関してもハイグロスコピッ ク領域の解析のみを対象とした. 熱水分移動と増殖モデルへの液相水分 の効果の組み込み, 更には表面風速の影響等の考慮は今後の課題である.

\section{参考文献}

1) 田中 俊彦, 村上 周三, 吉野博 : 浴室の必要換気量に関する実物実験 集 合住宅における換気設備に関する研究第 3 報, 日本建築学会論文報告集, No.314, pp.121-130, 1982.4

2) 松本 衛, 松下 敬幸: ハイグロスコピックの領域での気泡コンクリートの 吸放湿性状その 1 局所平衡線形モデルによる解析とその妥当性の検討, 日本建築学会論文報告集, No.302, pp.37-46, 1981.4

3) 松本 衛, 松下 敬幸: ハイグロスコピックの領域での気泡コンクリートの 吸放湿性状その 2 吸放湿過程におよぼす吸放湿履歴の影響と履歴のある 場合の解析法, 日本建築学会論文報告集, No.306, p.65-72, 1981.8

4) 近藤靖史, 長澤康弘, 藤村淳一 : 湿度による浮力の影響を考慮した室内温 熱環境予測, 室内空気中の水蒸気が空間温度分布に与える影響 (その 1), 日本建築学会計画系論文集, No.534, pp57-92, 2000.8

5) Yaw-Shyan Tsay, 加藤信介, 大岡龍三, 小金井真 : CFDを用いた対流と建 材内熱・水蒸気同時移動の連成解析による室内熱・湿気解析モデルの検討, 生産研究, 58 巻 1 号, pp55-58, 2006

6) Wickman, M., Gravesen, S., Nordvall, S.J., Pershagen, G. And Sundell, J: Indoor viable dust-bound microfungi in relation to residential characteristics, living habits, and symptoms in atopic and control children, J. Allergy and Clinical Immunology, 89, pp 752-759, 1992

7) Institute of Medicine: Damp Indoor Spaces and Health. National Academy Press. Washington, DC., 2004

8) 宇田川光弘 : 標準問題の提案, 日本建築学会第 15 回熱シンポジウムテキ スト, pp23-33, 1985

9) Nguyen Lu Phuong, Kazuhide Ito and Shigeki Onishi : Numerical prediction of particle transport passed through ventilator by CFD with Lagrangian method : AIVC 2010, Low energy and sustainable ventilation, Technologies for green buildings, Seoul, Korea, 1B-4 (20 pp)

10）尾崎明仁, 須貝高, 渡辺俊行, 龍有二, 赤司泰義, 山崎繁, 湯浅孝, 佐藤 章造 : 水分ポテンシャルによる湿気移動解析 湿流の駆動力 : 日本建築学 会計画系論文集, No.488, pp.17-24, 1996.10

11) K. Sedlbauer : Prediction of mould fungus formation on the surface of and inside building components, Dissertation University Stuttgart, 2001.

12) 伊藤一秀, 水野優 : 各種の湿度環境下における真菌類の増殖速度測定と増 殖挙動モデル：日本建築学会環境系論文集, Vol.74, No.636, pp193-199, 2009.2

13) 伊藤一秀, 水野優 : 反応拡散モデルによる真菌増殖の数理的形態解析 : 日 本建築学会環境系論文集, Vol.74, No.637, pp339-946, 2009.3

14) 陳晶, 伊藤一秀: 建材内の熱水分移動を考慮した真菌増殖の簡易予測 : 日 本建築学会環境系論文集, Vol.75, No.653, pp603-611, 2010.7

（2011年 3 月10日原稿受理，2011年 6 月20日採用決定） 